\title{
SPINAL CORD INJURIES RESULTING FROM SPORT. THE ISRAELI EXPERIENCE
}

\author{
By Abraham Ohry M.D. and Raphael Rozin M.D. \\ The Sir Ludwig Guttmann Spinal Cord Injury Unit, The Rehabilitation Center, \\ Sheba Medical Center Tel Hashomer, and Sackler School of Medicine, Tel Aviv \\ University.
}

Abstract. A brief account is given of patients who sustained a spinal cord injury while playing or practising sports or during leisure time physical activities. We have not attempted to analyse the various mechanisms of injury, but to record the striking fact that 13 of the 19 patients are tetraplegics. These devastating results could be prevented by adequate precautions and attention.

Key words: Spinal cord injuries; Sport; Leisure time activities.

'... and Abner said to Foab Let the young men now arise and play before us, And Foab said, Let them arise'... (II Samuel 2:I4).

\section{Introduction}

THROUGHOUT history sport has accompanied social cultural activities. Sport reflects the human being's desire for better physical and emotional achievement. Gymnastics, as defined by the Encyclopedia Britannica is a term 'signifying a system of physical exercises practised either to promote physical development or as a sport.' However, activity in sport may result in accidents and injuries. Many people participate in professional and competitive sport and enjoy sport in their leisure time. Unfortunately, in both fields we see victims of various activities.

We would like to present an account of our experience with patients who suffered spinal cord injuries during various sporting or leisure-time activities.

\section{Material}

Three hundred and seventeen patients were rehabilitated in our Department from June I973 to June I98I and all of these patients were transferred shortly after injury, or the onset of disease. Fifty eight also had brain injuries (or diseases). Seventy six suffered from cervical spine injuries resulting in tetraplegia. One hundred and twenty eight had dorso-lumbar spine injury, and 55 were admitted with non-traumatic spinal cord damage. There were I9 patients injured during sport or leisure time activities. Most of them were injured during the last 8 years. Only five such patients were dealt with before 1973. Table I summarises the patients' details. We see that most of the injuries were caused by diving into shallow water (eight patients), usually resulting in complete tetraplegia. Three patients were injured in parachute accidents; two were injured while landing and one was hit by another parachutist in the air, sustaining 
TABle I

\begin{tabular}{|c|c|c|c|c|c|}
\hline No. & Name & Age of Injury & Sex & Cause & Neurological Outcome \\
\hline I & A.G. & I 7 & M & Fall from 'omega' & complete D6 paraplegia \\
\hline 2 & A.S. & 26 & $\mathrm{M}$ & Fall from 'omega' & complete $C_{7}$ quadriplegia \\
\hline 3 & H.D. & I7 & $M$ & Diving into shallow water & incomplete $\mathrm{C}_{5}$ quadriplegia \\
\hline 4 & T.F. & 20 & $\mathbf{M}$ & Diving into shallow water & complete C6 quadriplegia \\
\hline 5 & M.E. & 24 & $\mathbf{M}$ & Parachuting & incomplete cauda equina \\
\hline 6 & M.Y. & 19 & $\mathrm{~F}$ & 'Shallow water' & complete $C_{5}$ quadriplegia \\
\hline 7 & A.M. & I9 & $\mathbf{M}$ & Trampoline & incomplete $\mathrm{C} 6$ quadriplegia \\
\hline 8 & F.Y. & 22 & $\mathbf{M}$ & Hit by car while bicycling & complete D8 paraplegia \\
\hline 9 & P.A. & 22 & M & $\begin{array}{l}\text { Free-fall parachuting-hit by } \\
\text { another parachutist }\end{array}$ & complete $\mathrm{D}_{5}$ paraplegia \\
\hline IO & K.E. & 22 & $\mathbf{M}$ & Fall from bicycle & complete D7 paraplegia \\
\hline I I & R.M. & 14 & $M$ & 'Shallow water' & complete $\mathrm{C}_{5}$ quadriplegia \\
\hline I 2 & G.O. & 18 & $\mathrm{~F}$ & 'Shallow water' & complete C6 quadriplegia \\
\hline 13 & C.M. & 17 & $M$ & 'Shallow water' & complete C6 quadriplegia \\
\hline 14 & S.E. & $2 \mathrm{I}$ & $\mathbf{M}$ & 'Shallow water' & complete $\mathrm{C}_{4}, 5$ quadriplegia \\
\hline 15 & P.G. & 19 & $M$ & Parachuting & incomplete cauda equina \\
\hline 16 & M.I. & I3 & $M$ & $\begin{array}{l}\text { Thrown down by friend while } \\
\text { playing }\end{array}$ & complete C6 quadriplegia \\
\hline I 7 & I.K. & 25 & M & 'Shallow water' & complete $\mathrm{C}_{3,4}$ quadriplegia \\
\hline I 8 & H.S. & $2 \mathrm{I}$ & M & $\begin{array}{l}\text { Jumped into empty swimming } \\
\text { pool at night }\end{array}$ & complete C6 quadriplegia \\
\hline I9 & G.D. & I9 & $M$ & Surfing & incomplete C6 quadriplegia \\
\hline
\end{tabular}


paraplegia. Two patients fell off an 'omega' construction, which is a long string attached to two points on a slope, with the person holding the 'omega' device and sliding downhill. Falls due to breaks in the construction, or falls from the middle of the slope may occur. Only one patient was injured while jumping from a trampoline: on the last jump his neck touched the peripheral bars causing tetraplegia. Two patients fell off bicycles and one was thrown off a surf-board which hit his neck. Two patients had quite rare accidents: one jumped into an empty swimming pool at night, and the other was thrown down by his friends while playing in the street. All underwent the usual rehabilitation process and continued their follow-up in our outpatients' clinic.

\section{Discussion}

The most striking fact which arises from this study is that none of these patients participated in competitive sport, but were active in playing and enjoying leisure time activities. The fact that in Israel we do not have a great deal of 'aggressive' or dangerous sports like rugby, American football, car racing, hang-gliding, boxing or mountaineering, may explain the absence of patients injured during such activities. Skiing is also very limited in our country. European and American physicians are aware of skiing, horseriding and hang-gliding accidents. Many of these accidents occur due to drunkenness and by not paying sufficient attention to safety rules and precautions. The literature concerning spinal cord injuries due to various sporting activities is well documented.

In Britain the problem of tetraplegia due to rugby is serious (Silver, I979; Williams and McKibbin, I978). Spinal injuries due to hang-gliding (Penschuck, 1980) and American football (Torg et al., 1979) are also well known in western countries. Spinal injuries due to various gymnastics such as the trampoline are also recorded (Evans, I979; Steinbrueck, I980; Rapp and Nicely, 1978; Fielding 1978). Motorcycle and bicycle accidents are also common (Walker, I979). As someone wrote 'with the sound of a lorry in his ears he (the cyclist), cannot hear the lesser sound of a car behind, he must check with his two eyes whether there is a following vehicle' (Walker, I979). It is true that with adequate planning and attention, most of these injuries could be prevented. Thirty four cases of quadriplegia from trampoline accidents (due to poor landing) were reported by Rapp and Nicely (1978). They concluded that there 'are dangers on the trampoline if it is poorly supervised'.

Parachuting is practised in Israel both by civilians and soldiers and usually traumatic landings result in dorsal or lumbar fractures. One of our patients had a very rare accident: while practising free-fall parachuting, his friend hit him on his back causing paraplegia.

Falls from the 'omega' device are not rare in civilian and military manoeuvres, but adequate equipment may prevent injuries. Water sports are also responsible for spinal cord injuries (Scher, I978; Green et al., I980; Steinbreuck and Paeslack, I980; Kiewerski, I980; Melamed and Ohry, I980). Most of the patients who were injured during these activities had cervical spine trauma. 


\section{SUMMARY}

There is an increasing number of people in Israel participating in educational, recreational, competitive and professional sports. However, the hazards of these various sporting activities must be remembered. Spinal Cord Injuries (S.C.I.) can result from several sports. We have had I9 patients suffering from S.C.I. due to: diving in shallow water (8 patients), falls off 'omegas' (2), parachuting (3), trampolines (I), falls off bicycles (2) and one while using a surf-board. One patient was thrown down by his friends and injured while playing and one jumped by mistake into an empty swimming pool.

Compared with other western countries we do not, as yet, have injuries from hang-gliding, horse riding, skiing, car-racing or mountaineering. We feel that most of these injuries could be averted by proper prevention programmes.

\section{RÉSUMÉ}

De plus en plus de gens en Israel s'adonnent aux sports en tant que loisirs, compétition ou profession. Il faut cependant garder à l'esprit les dangers de ces diverses activités sportives. Les traumatismes de la moëlle épinière peuvent être causés par plusieurs sports. Nous avons eu I9 patients traumatisés de la moëlle épinière, dû aux causes suivantes: plongeons en eau peu profonde, (8 patients); entraînement au parachutisme ou sauts en parachute (5); tremplins ( $\mathrm{I}$ ); chutes à bicyclette (2) et I accident sur planche à surf. Un patient fut blessé après avoir été jeté en l'air par ses amis pendant un jeu, alors qu'un autre avait sauté par erreur dans une piscine vide.

En comparaison avec d'autres pays de l'ouest, nous n'avons pas encore eu de traumatismes dus au delta-planning, à l'équitation, au ski, au sport automobile ou à l'alpinisme. Nous estimons que la majorité de ces traumatismes pourrait être éviteé grâce à des programmes de prévention adéquats.

\section{ZUSAMMENFASSUNG}

Immer mehr Leute treiben in Israel Sport als Hobby, Wettbewerb oder Beruf. Die Gefahren dieser verschedenen Sporttätigkeiten dürfen jedoch nicht vergessen werden. Rückenmarkverletzungen können durch mehrere Sportformen verursacht werden.

Wir haben I9 Patienten mit Rückenmarkverletzungen behandelt; die Ursachen waren: Kopfsprünge in niedriges Wasser (8 Patienten); Trainieren zum Fallschirmsprung oder Fallschirmsprünge (5); Trampolin (I); Stürze vom Fahrrad (2) und I Unfall mit Surf-Brett. Ein Patient wurde verletzt als seine Freunde ihn in die Luft warfen während einem Spiel, und ein anderer sprang aus Versehen in ein leeres Swimming Pool.

In Vergleich mit anderen westlichen Ländern haben wir noch keine Verlezungen die vom Delta-Planen, Reiten, Skifahren, Autorennen oder Bergsteigen verursacht worden. Wir meinen, dass die meisten dieser Verletzungen durch passende Vorbeugungsprogramme vermeidet werden können.

\section{REFERENCES}

EnCyClopedia Britannica, (1960). Volume i I, (Gymnastics), London.

Evans, R. F. (1979). Tetraplegia caused by gymnastics. Brit. Med. F., 2, 732.

Fielding, J. W., Fietti, V. G. \& Mardan-Bey, T. H. (I978). Athletic injuries to the atlantoaxial articulation. Amer. F. Sports Med., 6, 226-231.

Green, B. A., Gabrielsen, M. H., Hall, W. J. \& O'Heir J. (I980). Analysis of swimming pool accidents resulting in spinal cord injury. Paraplegia, 18, 94-100.

KIEWERSKI, J. (1980). Cervical spine injuries caused by diving into water. Paraplegia, I8, IOI-IO5.

Melamed, Y. \& OHry, A. (1980). The treatment and neurological aspects of diving accidents in Israel. Paraplegia, 18, I 27-132.

PensChuCK, C. (1980). Causes of injury in hang-gliding. Chirug., 51, 336-340. 
Rapp, G. F. \& Nicely, P. G. (1978). Trampoline injuries. Amer. F. Sports Med., 6, 260-27I.

Scher, A. T. (1978). Spinal cord injuries due to diving accidents. F. Sports Med. Phys. Fitness., 18, 67-70.

Silver, J. R. (I979). Rugby injuries to the cervical cord. Brit. Med. F., I, I92-3.

Steinbreuck, K. \& Paeslack, V. (I980). Analysis of I39 spinal cord injuries due to accidents in water sports. Paraplegia, 18, 86-93.

SteinBreUCK, K. (I969). Trampoline jumping. Med. Sport, 20, I20-I 26.

WALKer, H. M. (I979). Motorcycle and bicycle accidents. Brit. Med. F., I, 413.

Williams, J. P. \& McKibBin, B. (1978). Cervical spine injuries in rugby union football. Brit. Med. F., 2, 1747. 